\title{
THE DUSKY SALAMANDER DOES NOT OCCUR IN SASKATCHEWAN
}

FREDERICK W. SCHUELER, Herpetology Section, National Museum of Natural Sciences, Box 3443, Station D, Ottawa. K1P 6P4

Since no one has ever supposed that the Dusky Salamander, Desmognathus fuscus, does occur in Saskatchewan, or indeed anywhere northwest of Indiana, except for a recently introduced population in southeastern Kansas, it would seem pointless to mention its absence, were it not for a specimen in the collection of the Museum of Comparative Zoology at Harvard University (MCZ 1572) labelled "Cedar Lake Saskatchewan."3 2 This specimen has been mentioned by Dunn and Preston who have doubted its authenticity on zoogeographic grounds. ${ }^{5} 8$ It was not mentioned by Bishop, Logier and Toner, or Cook. ${ }^{1} 64$

During a recent visit to the $M C Z$, the author was able to examine this specimen, and here reports information about it which casts substantive doubt on its authenticity. In the MCZ amphibian catalogue, this specimen falls among collections which were entered without any record of the date received or when they were catalogued, between MCZ 1478, received 18 October 1878 , and $M C Z$ 1612 , received 10 November 1879 . There are eight collections among these from the present province of Manitoba. The catalogue entries for these collections are listed in Table 1. No dates of collection are noted for any, but there are fish in the MCZ from this area collected by Scudder with a date of collection of 1860 .

Two things are immediately apparent from Table 1. First these specimens did not come from Saskatchewan as a province, which did not exist in 1878-1879. The Gazetteer of Canada does not list a Cedar Lake in Saskatchewan. "Saskat- chewan" here refers only to the river, so that "Cedar Lake" is Cedar Lake, Manitoba, at the mouth of the Saskatchewan River. Dunn and Preston correctly located Cedar Lake, so the "Saskatchewan" on the bottle label is doubtless a recent error of interpretation. 5 8 Second, at the time of cataloguing MCZ 1572 was considered an Ambystoma ("Amblyst" is a truncation of "Amblystoma," a name formerly used for this genus). Ambystoma tigrinum, the Tiger Salamander, is the only salamander known to occur in the Canadian prairies, though $A$. laterale, the Bluespotted Salamander, is found in eastern Manitoba and the southern Interlake. ${ }^{8}$

Four of the collections of Wood Frogs were not assigned a name; this hesitancy was doubtless due to the problem of identifying Wood Frogs in an era in which they were divided into three highly artificial species. ${ }^{7}$ The specimens were subsequently identified as Rana cantabrigensis, and are perfectly plausible western or southern Manitoban Rana sy/vatica; five are middorsally striped and three are unstriped, which is the expected frequency there. ${ }^{10}$

The specimen bottle contains a recently written label, a loose metal tag with the number 1572 , a loose paper label pencilled with "Saskatchewan Riv. Brit. Am. S.H. Scudder," and a half dried-up Dusky Salamander with 15 costal grooves, a keeled tail, and a snout-vent length of about $37 \mathrm{~mm}$. None of the other collections listed in Table 1 are dried, the metal tags with which they are identified (identical in kind to that with MCZ 1572) are all tied to the specimens, and except for MCZ 1562, all the tags are tied on with 


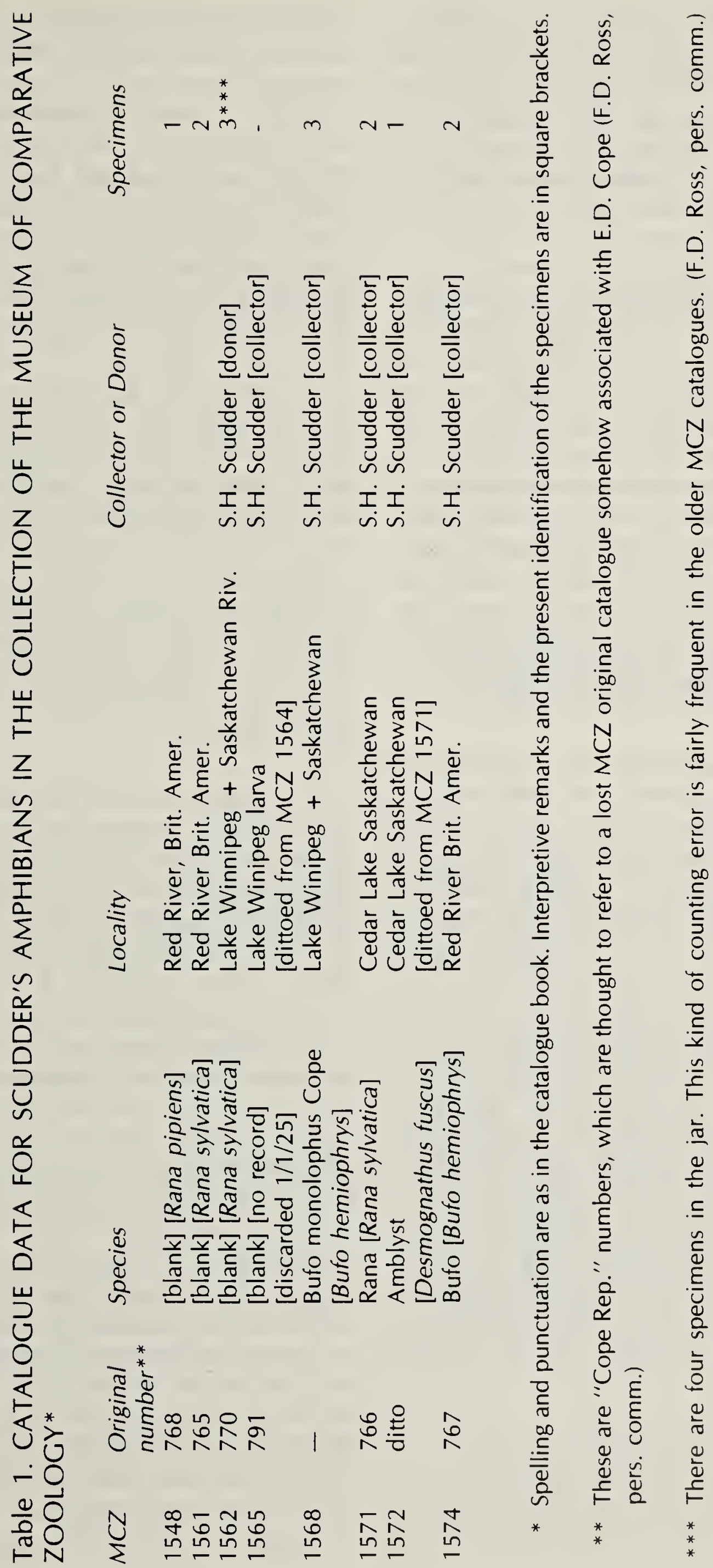


the same kind of coarse brown and white string. When there are more specimens than there are metal tags the specimens are linked together with thread. MCZ 1572 is also the only lot among these in which the locality given on the pencilled label in the bottle is different from that in the catalogue book.

Samuel H. Scudder was an entomologist. "In the summer of 1860 [he] made a collecting trip to Lake Winnipeg and the lower Saskatchewan... Among the butterflies [he] found at the mouth of the Saskatchewan [and] collected with difficulty on account of the mosquitos [was] a delicately marked and exquisitely pretty bluet," which was subsequently named Scudder's Blue (Lycaena scudderi Edwards). He was also a general naturalist, because he brought back amphibians and fish to the $M C Z$, and later compiled a list of all zoological generic names. ${ }^{11}$

In a book published under the name of "A. Rochester Fellow" in 1886 (in which he further styles himself "Francis Lutterby $^{\prime \prime}$ ) Scudder gives an account of this trip, which was made to observe the solar eclipse of July 1860 from Cumberland House.12 "The [United States] Government had despatched two of its astronomers on this six-thousand-mile journey for the information they were to gain on this single day, while a university museum [i.e. the MCZ] had added an assistant for the work, that opportunity might be given through him to increase its stores from the little-explored regions through which the expedition would pass." (p. 10-11) They never reached Cumberland House, and observed the eclipse through clouds from a muskeggy camp nearly inundated by the Saskatchewan River.

The book is mostly an account of the difficulties of travel and mosquitos, and Scudder seems as shy of dates as he is of his name. The party traveled by canoe up
Lake Winning to Grand Rapids, then through Cedar Lake to the Pas, and then returned. The trip took 42 days centred on "mid-July." There is no mention of collecting amphibians, though they carried alcohol and preserved birds, fish, and mammals in it, and also collected many insects. The factor at Cedar Lake House, a Mr. De Leon, is mentioned as filling an alcohol can with "pelicans and other small fry for our naturalist." (p. 81)

I conclude that the original identification as Ambystoma, the loose tag when the other collections were tied, and the dried condition of the specimen when the other collections were not dried out, indicate that some error, in which a Dusky Salamander was substituted for the original specimen, occurred between the time MCZ 1572 was entered in the catalogue book and the time the systematic card file was established around 1900.

The range of neither the Blue-spotted nor the Tiger salamander, as presently known, extends to Cedar Lake, though the former approaches the southern part of Cedar Lake from the southeast and the latter from the southwest. ${ }^{8}$ The pencilled label "Saskatchewan Riv. Brit. Am." may be the correct locality, and "Cedar Lake" may be dittoed from MCZ 1571 in the catalogue book. (It is suggestive of error that the "original number" is also dittoed, though Scudder seemed to regard Cedar Lake as a wide part of the Saskatchewan River. ${ }^{12}$ ) In any event, the specimen could not have come from within the known range of the Tiger Salamander along the course of the Saskatchewan River in Saskatchewan, because Scudder's party did not go upstream past The Pas. In those days the shores of Lake Winnipeg were on the main thoroughfare of travel in this region, and while roads built along the highest land now make some species of amphibians more accessible, Scudder, in his soggy lake-side camps, may have been 
more apt to encounter salamanders than is the modern collector. ${ }^{9}$

\section{Acknowledgements}

Help has come from many people in tracking down these facts. Frank Ross assumed that there would be Canadian problems in the MCZ Catalogue. Francis Cook, Don McAllister, Dan Brunton, and Hugh Danks helped to locate information on Scudder, and Bill Preston and Colleen Nelson found the account of his travels. The visit to the MCZ was made in connection with work on Rare and Endangered Canadian Fish, supported by the Department of Fisheries and Oceans through a contract with the National Museum of Natural Sciences, Ottawa.

1 BISHOP, S.C. 1947. Handbook of salamanders: the salamanders of the United States, of Canada, and of Lower California. Comstock Press, Ithaca N.Y. 555 pp.

2 COLLINS, J.T. 1974. Amphibians and reptiles in Kansas. Univ. of Kansas Mus. of Nat. History, Public Education Series 1: $x+283$ pp.

${ }^{3}$ CONANT, R. 1975. A field guide to reptiles and amphibians of eastern and central North America. 2nd edition. Houghton Mifflin Co., Boston, xviii +429 pp.

4 COOK, F.R. 1984. Introduction to Canadian amphibians and reptiles. National Mus. of Nat. Sciences, National Mus. of Canada, Ottawa. 200 pp.

5 DUNN, E.R. 1926. The salamanders of the family Plethodontidae. Smith College Fiftieth Anniversary Publ. 7:1-441.

6 LOGIER, E.B.S. and G.C. TONER 1961. Check list of the amphibians and reptiles of Canada and Alaska. Life Sciences Div., Royal Ont. Mus., Contrib. No. 53:1-92.

7 MARTOF, B.S. and R.L. HUMPHRIES 1959. Geographic variation in the Wood Frog, Rana sylvatica. Am. Midl. Nat. 61:350-389.
8 PRESTON, W.B. 1982. The amphibians and reptiles of Manitoba. Man. Mus. of Man and Nature, Winnipeg. $128 \mathrm{pp}$.

9 SCHUELER, F.W. and F.D. ROSS 1986. Range extensions for hylid frogs in Manitoba. Blue Jay 44(3):168-173.

10 SCHUELER, F.W. and F.R. COOK 1980. Distribution of the mid-dorsal stripe dimorphism in the Wood Frog, Rana sylvatica, in eastern North America. Can. J. of Zool. 58:1643-1651.

1 SCUDDER, S.H. 1882. Nomenclator Zoologicus - An alphabetical list of all generic names that have been employed by naturalists for recent and fossil animals from the earliest times to the close of the year 1879. Bull. U.S. National Mus. 19:xix $+376+340 \mathrm{pp}$.

12 SCUDDER, S.H. [pseudonym A ROCHESTER FELLOW] 1886. The Winnipeg country or roughing it with an eclipse party. Cupples, Upham \& Co. Boston. 144 pp.

13 SCUDDER, S.H. 1901. My first namesake. Ottawa Nat. 15:121-122.

\section{CRESTON VALLEY WILDLIFE MANAGEMENT AREA - 20 YEARS}

The Creston Valley Wildlife Management Area is celebrating its 20th birthday on 2 October 1988. A summer program of events is culminated by an official birthday celebration on that date, with special events all day including the filling and sealing of a time capsule. For more information contact C.V.W.M.A., Box 460, Creston, British Columbia V0B $1 \mathrm{GO}$ or (604) 428-3260. 